\title{
INVASIVE ALIEN FRESHWATER SNAIL SPECIES IN THE KRUGER National Park, South Africa
}

\author{
KENNÉ N. DE KOCK \\ CORNELIUS T. WOLMARANS \\ School of Environmental Sciences and Development (Zoology) \\ North-West University \\ Potchefstroom \\ South Africa
}

Correspondence to: Kenné de Kock

e-mail: kenne.dekock@nwu.ac.za

Postal Address: School of Environmental Sciences and Development, North-West University, Private Bag X6001, Potchefstroom, 2520, South Africa

\begin{abstract}
An account is given of all invasive alien freshwater snail species samples found in the Kruger National Park currently on record in the National Freshwater Snail Collection (NFSC) database. This report mainly focuses on samples collected during surveys of selected water bodies in the Kruger National Park (KNP) during 1964, 1995, 2001 and 2006. The progress made by four alien invasive freshwater snail species, Lymnaea columella, Physa acuta, Aplexa marmorata and Tarebia granifera, in colonising water bodies since first being recorded in the KNP is addressed. The results clearly show that all four species are in the process of becoming more widespread than they were when first recorded. However, $T$. granifera is the only one of these species of which exceptionally dense populations were encountered in several water bodies. All indications are that this species could already have had a negative impact on the species diversity of molluscs in these water bodies, and it is recommended that the situation be closely monitored.
\end{abstract}

Keywords: Invader snails, Lymnaea columella, Physa acuta, Aplexa marmorata, Tarebia granifera

In an assessment of the ecological impact and economic consequences of the introduction and dispersal of invasive alien organisms into southern African aquatic ecosystems, Ashton et al. (1986) concluded that available information pertaining to molluscs was limited. In his revision of the available knowledge on the biology of invasive gastropods and the impact they may have on systems they have colonised in South Africa, Appleton (2003) lists four species as being invasive or as becoming so. Two of these, Lymnaea columella (Say 1817) and Physa acuta (Draparnaud 1805), were introduced in the early 1940s (Brown 1994, Appleton \& Brackenbury 1998), while Aplexa marmorata (Guilding 1828) was collected for the first time in this country in 1986 (Appleton et al. 1989). The most recently introduced species, Tarebia granifera (Lamarck 1816), was reported for the first time in Africa by Appleton and Nadasan (2002) after it was discovered in 1999 in a reservoir supplying water to a paper mill in KwaZulu-Natal. In a recent survey of the mollusc fauna of the KNP, we collected all four of these invasive alien species from several water bodies. Although more than 25 different mollusc species from the KNP are on record in the NFSC database, no other alien mollusc species are on record. This computerised database was compiled from more than 18000 samples, the majority of which were collected during surveys conducted by staff of government and local health authorities. Samples were then dispatched to the former Snail Research Unit at the Potchefstroom University for identification. However, at least $25 \%$ of these samples were collected by Snail Research Unit staff during research projects aimed at studying the taxonomy, geographical distribution and ecology of the indigenous freshwater mollusc fauna. The database, along with more than 35000 vials of preserved species samples, is located at the Potchefstroom Campus of the North-West University. The aim of the present contribution is to evaluate the progress of the four alien species on record in colonising water bodies in the KNP by comparing the results of our recent survey with data in the NFSC database, dating back to 1959

\section{METHODS AND MATERIALS}

During our recent survey (Wolmarans \& De Kock 2006) we concentrated mainly on water bodies that were screened for molluscs in 1995 (De Kock \& Wolmarans 1998) and 2001 (De Kock et al. 2002). Molluscs were collected by means of aluminium scoops, preserved in alcohol, identified by the first author and subsequently incorporated into the NFSC. Sites where the four alien invasive snail species were recovered, records of previous collections extracted from the database of the NFSC, as well as sites positive for other mollusc species but negative for the four alien species, were plotted on a map. Information on the type of water body, the grid reference and the date of collection for each locality where freshwater mollusc species were recovered during our 1995, 2001 and 2006 surveys are presented in Table 1.

\section{RESULTS}

Of the four alien invader freshwater snail species under discussion, only three samples of L. columella from the KNP were recorded prior to our 1995 survey. Although samples of this species were recovered from only a single locality during our extensive survey in 1995 (De Kock \& Wolmarans 1998), the results of our 2001 (De Kock et al. 2002) and our 2006 (Wolmarans \& De Kock 2006) surveys added eight and two new localities to its distribution respectively (see Table I). The collection sites of all samples of L. columella currently on record in the NFSC database for the KNP are depicted in Fig. 1.

The single sample of $P$. acuta recovered from the Sabie River in 1995 (De Kock \& Wolmarans 1998) was the first record of this species from the KNP reported in print (see Table I). Two new localities were added as a result of the survey in 2001 (De Kock et al. 2002) and another two as a result of our 2006 survey (Wolmarans \& De Kock 2006) (see Table I). The collection sites of all samples of P. acuta currently on record in the NFSC database for the KNP are depicted in Fig. 1. 


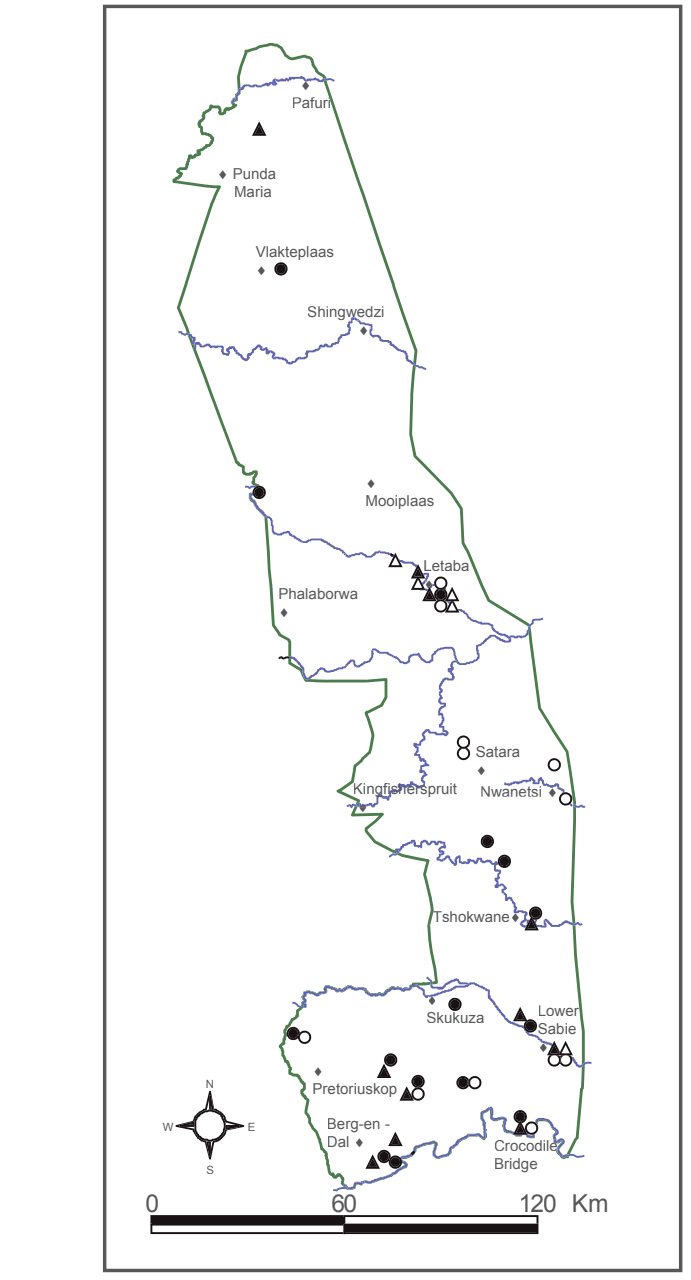

FIGURE 1

Distribution of the alien invader freshwater snail species Lymnaea columella $(\bullet)$, Physa acuta $(\Delta)$, Aplexa marmorata $(\boldsymbol{\Lambda})$, Tarebia granifera $(\circ)$ and rainfall monitoring stations $(\bullet)$.

Although the results of the survey in 1995 (DeKock \& Wolmarans 1998) yielded only one sample of A. marmorata, it was also the first recorded instance of the species in the KNP. Respectively, seven and three new localities were added to the list as a result of our 2001 (De Kock et al. 2002) and 2006 (Wolmarans \& De Kock 2006) surveys (see Table I). The collection sites of all $A$. marmorata samples currently on record in the NFSC database for the KNP are depicted in Fig. 1.

The recently introduced alien invader species, T. granifera, (Appleton \& Nadasan 2002; Appleton 2003), was collected from 12 water bodies during our 2006 survey (Wolmarans \& De Kock 2006) (see Table I). These collection sites are depicted in Fig. 1.

\section{DISCUSSION}

Lymnaea columella was not mentioned in a monograph by Connolly (1939) after an in-depth revision of the extensive mollusc material collected by him and many other researchers. It is therefore reasonable to conclude that this species was extremely rare in South Africa before 1944 (Van Eeden \& Brown 1966; Brown 1967; 1978; 1980). According to Brown (1994), the earliest record of L. columella dates back to 1942 when it was found near Somerset West. Since then, 2302 samples of this species have been recorded in the NFSC database. These collection sites are distributed over 353 loci ( $(116$ square degrees), ranking $L$. columella the third-most-widespread freshwater snail species in South Africa. It is only surpassed by the two indigenous species, Bulinus tropicus (Krauss 1848) (939 loci) and
Lymnaea natalensis (Krauss 1848) (616 loci). In 1964, during the first concentrated effort to systematically survey the KNP for freshwater molluscs, L. columella was collected in two localities (Oberholzer \& Van Eeden 1967). However, it was identified five years earlier in a collection from the Crocodile River in 1959. An extensive survey of water bodies in the KNP in 1995 (De Kock \& Wolmarans 1998) yielded only one new collection site. The fact that only three new collection sites were recorded for the 35 years up to 1995 suggests that L. columella has been less successful in invading water bodies in the KNP than elsewhere in South Africa (De Kock et al. 1989). However, 10 new localities were recorded during our surveys in 2001 and 2006 (see TableaI) and it would seem that this species has now become well established, especially in the southern areas of the KNP.

With regard to $P$. acuta, the species was reported by Van Bruggen (1964) from a single locality in Pretoria, thereby establishing the first published record of the species in South Africa, although the oldest record in the NFSC database dates back to the Umsindusi River, Pietermaritzburg, in 1954. Since then it has dispersed and colonised many water bodies in several South African river systems (Hamilton-Attwell et al. 1970, De Kock et al. 1989). It is therefore rather surprising that the first record of this species in the KNP was only established more than five decades after its introduction into this country, during our 1995 survey (De Kock \& Wolmarans 1998). In view of the fact that only four new collection sites were added as a result of our extensive 2001 (De Kock et al. 2002) and 2006 (Wolmarans \& De Kock 2006) surveys, it seems justifiable to regard $P$. acuta as a less aggressive invader than L. columella. This view is supported by the fact that, without exceptions, only a small number of P. acuta specimens were collected in any of the water bodies in which it was present. This is surprising in view of the fact that population densities as high as \pm 3000 $\mathrm{m}^{2}$ for this species were reported by Brackenbury and Appleton (1993), as well as a much higher reproductive rate than for the $r$ selected Bulinus tropicus (Brackenbury \& Appleton 1991), which is generally considered to be the most widespread freshwater snail species in South Africa (De Kock et al. 2002). Perhaps the fact that $P$. acuta commonly occurs in areas where sewerage pollution is obvious and that it seems to be closely associated with human activities (Brown 1994) might explain its relatively slow progress in colonising the relatively unpolluted freshwater habitats in the KNP. Appleton (2003) also mentions the fact that P. acuta has acquired the nickname of 'the sewage snail' and is often the only mollusc living in water with high levels of faecal pollution.

The first report of the presence of the more recently introduced invader species, A. marmorata, in South Africa was by Appleton et al. (1989) from specimens collected near Durban, KwaZuluNatal in 1983. These authors also reported two additional records for this species: one from KwaZulu-Natal and the other from Tzaneen, in Limpopo Province, collected in 1986 and 1988 respectively. According to Appleton (2003), A. marmorata is now widespread in the Durban area. The first sample of this species from the KNP was collected by us in 1995, just over a decade after it was first discovered in this country. This is much sooner than the five decades that elapsed before the presence of $P$. acuta was first recorded in the KNP after its introduction in the early 1940s. In view of the fact that both species were initially recorded in localities in KwaZulu-Natal, it seems justifiable to assume that $A$. marmorata might be a more aggressive invader of relatively undisturbed habitats. This is supported by the results in Fig. 1, which not only depicts the higher number of collection sites but also the wider distribution of $A$. marmorata in the KNP.

As mentioned earlier, the most recently introduced invader species of the four under discussion, Tarebia granifera, was reported for the first time in Africa by Appleton and Nadasan (2002). According to these authors, it was discovered in 1999 in 
TABLE 1

Positive and negative records of four alien invader freshwater mollusc species collected in water bodies in the Kruger National Park during surveys conducted in 1995, 2001 and 2006

\begin{tabular}{|c|c|c|c|c|c|c|c|c|}
\hline \multirow{2}{*}{$\begin{array}{l}\text { RAINFALL } \\
\text { MONITORING } \\
\text { STATION }\end{array}$} & \multirow[b]{2}{*}{ WATER BODY } & \multirow{2}{*}{$\begin{array}{l}\text { GRID } \\
\text { REFERENCE }\end{array}$} & \multicolumn{2}{|l|}{1995} & \multicolumn{2}{|l|}{2001} & \multicolumn{2}{|l|}{2006} \\
\hline & & & $\begin{array}{l}\text { Mollusc } \\
\text { species found }\end{array}$ & $\begin{array}{l}\text { Invader mollusc } \\
\text { species found }\end{array}$ & $\begin{array}{l}\text { Mollusc } \\
\text { species found }\end{array}$ & $\begin{array}{l}\text { Invader mollusc } \\
\text { species found }\end{array}$ & $\begin{array}{l}\text { Mollusc } \\
\text { species found }\end{array}$ & $\begin{array}{l}\text { Invader mollusc } \\
\text { species found }\end{array}$ \\
\hline \multirow[t]{2}{*}{ Berg en Dal } & Matjulu Spruit & $25^{\circ} 21^{\prime} \mathrm{S} ; 31^{\circ} 31^{\prime} \mathrm{E}$ & none & none & yes & $\begin{array}{l}\text { Lymnaea columella } \\
\text { Aplexa marmorata }\end{array}$ & yes & Lymnaea columella \\
\hline & Mlambane Spruit & $25^{\circ} 21^{\prime} \mathrm{S} ; 31^{\circ} 31^{\prime} \mathrm{E}$ & not surveyed & & yes & Aplexa marmorata & yes & none \\
\hline \multirow[t]{2}{*}{ Crocodile Bridge } & Crocodile River & $25^{\circ} 21^{\prime} \mathrm{S} ; 31^{\circ} 53^{\prime} \mathrm{E}$ & not surveyed & & not surveyed & & yes & Tarebia granifera \\
\hline & Gezantombi Dam & $25^{\circ} 20^{\prime} \mathrm{S} ; 31^{\circ} 52^{\prime} \mathrm{E}$ & none & & yes & $\begin{array}{l}\text { Lymnaea columella } \\
\text { Aplexa marmorata }\end{array}$ & yes & none \\
\hline \multirow[t]{5}{*}{ Lower Sabie } & Lower Sabie Dam & $25^{\circ} 07^{\prime} \mathrm{S} ; 31^{\circ} 56^{\prime} \mathrm{E}$ & not surveyed & & not surveyed & & yes & Tarebia granifera \\
\hline & Mpondo Dam & $25^{\circ} 12^{\prime} \mathrm{S} ; 31^{\circ} 43^{\prime} \mathrm{E}$ & not surveyed & & yes & Lymnaea columella & yes & Tarebia granifera \\
\hline & $\begin{array}{l}\text { Sabie River below } \\
\text { Lower-Sabie Dam } \\
\text { wall }\end{array}$ & $25^{\circ} 07^{\prime} \mathrm{S} ; 31^{\circ} 56^{\prime} \mathrm{E}$ & not surveyed & & & & yes & Tarebia granifera \\
\hline & Sabie River & $25^{\circ} 07^{\prime} \mathrm{S} ; 31^{\circ} 55^{\prime} \mathrm{E}$ & yes & $\begin{array}{l}\text { Lymnaea columella } \\
\text { Physa acuta } \\
\text { Aplexa marmorata }\end{array}$ & yes & $\begin{array}{l}\text { Physa acuta } \\
\text { Aplexa marmorata }\end{array}$ & yes & none \\
\hline & Sunset Dam & $25^{\circ} 06^{\prime} \mathrm{S} ; 31^{\circ} 54^{\prime} \mathrm{E}$ & not surveyed & & yes & Aplexa marmorata & none & \\
\hline \multirow[t]{4}{*}{ Pretoriuskop } & Mbyamiti River & $25^{\circ} 13^{\prime} \mathrm{S} ; 31^{\circ} 34^{\prime} \mathrm{E}$ & yes & none & yes & $\begin{array}{l}\text { Lymnaea columella } \\
\text { Aplexa marmorata }\end{array}$ & yes & none \\
\hline & $\begin{array}{l}\text { Mbyamiti River } \\
\text { weir }\end{array}$ & $25^{\circ} 13^{\prime} \mathrm{S} ; 31^{\circ} 37^{\prime} \mathrm{E}$ & yes & none & yes & none & yes & Tarebia granifera \\
\hline & Mestel Dam & $25^{\circ} 06^{\prime} \mathrm{S} ; 31^{\circ} 12^{\prime} \mathrm{E}$ & not surveyed & & yes & $\begin{array}{l}\text { Lymnaea columella } \\
\text { Aplexa marmorata }\end{array}$ & yes & Tarebia granifera \\
\hline & Shitlhave Dam & $25^{\circ} 08^{\prime} \mathrm{S} ; 31^{\circ} 19^{\prime} \mathrm{E}$ & none & & yes & none & yes & none \\
\hline \multirow[t]{3}{*}{ Skukuza } & Manzimahle Dam & $24^{\circ} 35^{\prime} \mathrm{S} ; 31^{\circ} 43^{\prime} \mathrm{E}$ & none & & yes & none & none & \\
\hline & Olifantdrinkgat & $24^{\circ} 53^{\prime} \mathrm{S} ; 31^{\circ} 44^{\prime} \mathrm{E}$ & none & & yes & none & yes & none \\
\hline & Vervoer Dam & $25^{\circ} 07^{\prime} \mathrm{S} ; 31^{\circ} 29^{\prime} \mathrm{E}$ & none & & yes & $\begin{array}{l}\text { Lymnaea columella } \\
\text { Aplexa marmorata }\end{array}$ & none & \\
\hline \multirow[t]{5}{*}{ Tshokwane } & Kumana Dam & $24^{\circ} 37^{\prime} \mathrm{S} ; 31^{\circ} 47^{\prime} \mathrm{E}$ & none & & yes & none & yes & none \\
\hline & Mazithi Dam & $24^{\circ} 43^{\prime} \mathrm{S} ; 31^{\circ} 50^{\prime} \mathrm{E}$ & none & & yes & none & yes & none \\
\hline & $\begin{array}{l}\text { Nwaswitsontso } \\
\text { River }\end{array}$ & $24^{\circ} 37^{\prime} \mathrm{S} ; 31^{\circ} 47^{\prime} \mathrm{E}$ & yes & none & yes & none & yes & none \\
\hline & Orpen Dam & $24^{\circ} 47^{\prime} \mathrm{S} ; 31^{\circ} 53^{\prime} \mathrm{E}$ & yes & none & yes & Lymnaea columella & yes & Aplexa marmorata \\
\hline & Silolweni Dam & $24^{\circ} 29^{\prime} \mathrm{S} ; 31^{\circ} 50^{\prime} \mathrm{E}$ & none & & yes & none & none & \\
\hline \multirow[t]{2}{*}{ Nwanetsi } & Gudzani Dam & $24^{\circ} 22^{\prime} \mathrm{S} ; 31^{\circ} 55^{\prime} \mathrm{E}$ & yes & none & yes & none & yes & Tarebia granifera \\
\hline & $\begin{array}{l}\text { Nwanetsi Water } \\
\text { Hole }\end{array}$ & $24^{\circ} 28^{\prime} \mathrm{S} ; 31^{\circ} 58^{\prime} \mathrm{E}$ & yes & none & yes & none & yes & Tarebia granifera \\
\hline \multirow[t]{2}{*}{ Satara } & Nkaya Pan & $24^{\circ} 31^{\prime} \mathrm{S} ; 31^{\circ} 45^{\prime} \mathrm{E}$ & none & & yes & none & yes & none \\
\hline & Nsemani Dam & $24^{\circ} 23^{\prime} \mathrm{S} ; 31^{\circ} 43^{\prime} \mathrm{E}$ & none & & yes & none & none & \\
\hline \multirow[t]{4}{*}{ Houtboschrand } & Ngotso Dam & $24^{\circ} 10^{\prime} \mathrm{S} ; 31^{\circ} 43^{\prime} \mathrm{E}$ & not surveyed & & none & & none & \\
\hline & Piet Grobler Dam & $24^{\circ} 13^{\prime} \mathrm{S} ; 31^{\circ} 38^{\prime} \mathrm{E}$ & not surveyed & & yes & none & yes & Tarebia granifera \\
\hline & Timbavati River & $24^{\circ} 16^{\prime} \mathrm{S} ; 31^{\circ} 38^{\prime} \mathrm{E}$ & none & & yes & none & yes & none \\
\hline & $\begin{array}{l}\text { Timbavati River } \\
\text { below Piet Grobler } \\
\text { Dam wall }\end{array}$ & $24^{\circ} 12^{\prime} \mathrm{S} ; 31^{\circ} 38^{\prime} \mathrm{E}$ & not surveyed & & yes & none & yes & Tarebia granifera \\
\hline Phalaborwa & Sable Dam & $23^{\circ} 56^{\prime} \mathrm{S} ; 31^{\circ} 14^{\prime} \mathrm{E}$ & not surveyed & & yes & none & none & \\
\hline \multirow[t]{4}{*}{ Letaba } & Engelhard Dam & $23^{\circ} 50^{\prime} \mathrm{S} ; 31^{\circ} 38^{\prime} \mathrm{E}$ & $\begin{array}{l}\text { no suitable } \\
\text { habitat }\end{array}$ & & yes & Physa acuta & yes & $\begin{array}{l}\text { Physa acuta } \\
\text { Aplexa marmorata } \\
\text { Tarebia granifera }\end{array}$ \\
\hline & Letaba River & $23^{\circ} 45^{\prime} \mathrm{S} ; 31^{\circ} 22^{\prime} \mathrm{E}$ & none & none & yes & Physa acuta & yes & $\begin{array}{l}\text { Physa acuta } \\
\text { Aplexa marmorata }\end{array}$ \\
\hline & $\begin{array}{l}\text { Letaba River below } \\
\text { Engelhard Dam } \\
\text { wall }\end{array}$ & $23^{\circ} 50^{\prime} S ; 31^{\circ} 39^{\prime} \mathrm{E}$ & $\begin{array}{l}\text { no suitable } \\
\text { habitat }\end{array}$ & & yes & none & yes & $\begin{array}{l}\text { Lymnaea columella } \\
\text { Physa acuta } \\
\text { Tarebia granifera }\end{array}$ \\
\hline & Olifants River & $24^{\circ} 31^{\prime} S ; 31^{\circ} 41^{\prime} \mathrm{E}$ & $\begin{array}{l}\text { no suitable } \\
\text { habitat }\end{array}$ & & $\begin{array}{l}\text { no suitable } \\
\text { habitat }\end{array}$ & & yes & Physa acuta \\
\hline \multirow[t]{2}{*}{ Mooiplaas } & Grootvlei Dam & $23^{\circ} 20^{\prime} \mathrm{S} ; 31^{\circ} 30^{\prime} \mathrm{E}$ & not surveyed & & yes & none & yes & none \\
\hline & Pioniers Dam & $23^{\circ} 31^{\prime} \mathrm{S} ; 31^{\circ} 23^{\prime} \mathrm{E}$ & yes & none & yes & none & yes & none \\
\hline \multirow[t]{4}{*}{ Shingwedzi } & Kanniedood Dam & $23^{\circ} 08^{\prime} \mathrm{S} ; 31^{\circ} 27^{\prime} \mathrm{E}$ & not surveyed & & yes & none & yes & none \\
\hline & Krapkuil Dam & $23^{\circ} 14^{\prime} \mathrm{S} ; 31^{\circ} 18^{\prime} \mathrm{E}$ & none & & yes & none & yes & none \\
\hline & Shisa Spruit & $22^{\circ} 57^{\prime} \mathrm{S} ; 31^{\circ} 15^{\prime} \mathrm{E}$ & not surveyed & & yes & none & none & \\
\hline & Sirheni Dam & $22^{\circ} 56^{\prime} \mathrm{S} ; 31^{\circ} 14^{\prime} \mathrm{E}$ & not surveyed & & yes & Lymnaea columella & yes & none \\
\hline Punda Maria & $\begin{array}{l}\text { Klopperfontein } \\
\text { Dam }\end{array}$ & $22^{\circ} 37^{\prime} \mathrm{S} ; 31^{\circ} 10^{\prime} \mathrm{E}$ & none & & yes & none & yes & Aplexa marmorata \\
\hline Pafuri & Luvuvhu River & $22^{\circ} 26^{\prime} S ; 31^{\circ} 13^{\prime} \mathrm{E}$ & not surveyed & & $\begin{array}{l}\text { no suitable } \\
\text { habitat }\end{array}$ & & none & none \\
\hline
\end{tabular}


a reservoir supplying water to a paper mill at Mandeni, $95 \mathrm{~km}$ north-east of Durban. Subsequently, the collection of another 16 samples of T. granifera - 14 from KwaZulu-Natal and two from the Crocodile River at Malelane in the KNP - were reported by Appleton (2005). No specimens of T. granifera were found during either of our 1995 and 2001 surveys of selected water bodies in the KNP; however, during our 2006 survey, 12 localities were recorded (see Table I). From the fact that the first record of this species in South Africa was only collected in 1999 and the fact that no specimens were found during our 1995 and 2001 surveys, it seems reasonable to assume that T. granifera did not reach the KNP earlier than 1999. The results in Fig. 1 support reports in the literature that this species readily becomes invasive after its introduction into a new country. It took $A$. marmorata and L. columella 10 and 47 years respectively to invade more than 10 water bodies in the KNP, while T. granifera accomplished this in only about five years.

According to the data in the NFSC database, only relatively small numbers of specimens of the L. columella, P. acuta and A. marmorata could be collected in each locality in the KNP. In contrast to this, extremely high numbers of T. granifera were found at five of the 12 collection sites during our 2006 survey. Appleton (2003) also reports very high numbers of this species from two habitats in KwaZulu-Natal. In a discussion of the ecological impacts of invasive snails, Appleton (2003) raises the point that high densities of alien snails must surely reduce the food available to indigenous grazing invertebrates and that in high-density situations, physical interaction between invasive snails and indigenous invertebrates could also be important. The negative effects of increased physical contact between snails in high density situations on reproduction and growth have been reported by several authors in the past (DeWitt 1954, Chernin \& Michelson 1957, Berrie 1968). In Puerto Rico and Cuba, invasion by $T$. granifera was also associated with the disappearance of an indigenous snail species (Pointier 1999). In accordance with these observations, a marked decrease in species diversity was found at five of the 12 sites where T. granifera was collected in 2006, as compared to the results of our survey in 2001.

From Fig. 1 it is clear that three of the four invader species have become well established in the southern part of the KNP. The success of L. columella as invader is partly ascribed to its amphibious habits (Van Eeden \& Brown 1966, Appleton 2003), wide temperature tolerance (Brown 1994) and its relatively high intrinsic rate of natural increase (De Kock et al.1989). Likewise, Tarebia granifera is $r$-selected and also parthenogenetic (Appleton 2003); these attributes contribute to its success as invader.

While the introduction into South Africa of L. columella, P. acuta and T. granifera was probably via the aquarium trade, it seems possible that $A$. marmorata has been present in south-eastern Africa for at least 160 years (Appleton 2003). The airborne dispersal of flightless small animals is an established fact and is known to be facilitated mainly by dispersal agents such as wind, insects and birds (Rees 1965). According to Rees (1965), it is well documented that birds play a more important role in the dispersal of molluscs than either wind or insects. To substantiate this statement, he lists a number of cases reported in the literature that incriminate bird species (ducks, plovers, herons) as dispersal agents for a variety of gastropod and bivalve species. Passive transport by water currents in lotic habitats can obviously play a role in the dispersal of aquatic fauna, and it has been found that $P$. acuta is also capable of actively migrating upstream against the current (Appleton \& Branch 1989). Immigration from refugia after heavy floods also plays an important role in the recolonisation of a habitat, as reported by Brackenbury and Appleton (1993) for P. acuta in the Umsindusi River, KwaZulu-Natal. Egg clutches and snails can also be successfully transported over relatively short distances on the hooves of animals, which could have contributed to the gradual colonising of proximate suitable habitats after a first introduction to the Kruger National Park. However, birds most probably contributed largely towards the spreading of the alien invader snail species - a view supported by the discontinuous distribution pattern plotted for L. columella, P. acuta and A. marmorata in Fig. 1 and also by the presence of T. granifera in isolated localities such as the Mestel Dam.

\section{CONCLUSIONS}

From the results of this investigation it is clear that all the invasive alien freshwater snail species currently present in the Kruger National Park are in the process of becoming more widespread. However, the rate at which $T$. granifera seems to be spreading is cause for concern, and we fully support the view of Appleton (2005) that this is the species that should be monitored.

\section{ACKNOWLEDGEMENTS}

We are indebted to the South African National Parks for permission to conduct our research and for partially sponsoring the surveys; to Prof L. van Rensburg, Director: Research Focus Area, Environmental Science and Sustainable Management of the Potchefstroom Campus of the North-West University for financial support and to Prof L.H. du Preez of the School of Environmental Sciences and Development of the Potchefstroom Campus of the North-West University for assistance in compiling the map.

\section{REFERENCES}

Appleton, C.C. 2003. Alien and invasive fresh water Gastropoda in South Africa. African Journal of Aquatic Science, 28: 69-81.

Appleton, C.C. 2005. Invasive freshwater invertebrates in South Africa. Plenary address to the Congress of the Zoological Society of Southern Africa, Grahamstown, July, 2005.

Appleton, C.C. \& Brackenbury, T.D. 1998. Introduced freshwater gastropods in Africa with special reference to Physa acuta. In: Madsen, H., Appleton, C.C. \& Chimbari, M. (eds). Proceedings of a workshop on medical malacology in Africa, September 1997. Harare: Danish Bilharziasis Laboratory, pp. 22-26.

Appleton, C.C., Brackenbury, T.D. \& Tonin, A.F.G. 1989. Physa mosambiquensis (Clessin, 1886) rediscovered? South African Journal of Zoology, 24: 340-344.

Appleton, C.C. \& Branch, G.M. 1989. Upstream migration by the invasive snail Physa acuta in Cape Town, South Africa. South African Journal of Science, 85: 189-190.

Appleton, C.C. \& Nadasan, D.S. 2002. First report of Tarebia granifera (Lamarck, 1816) (Gastropoda: Thiaridae) from Africa. Journal of Molluscan Studies, 68: 399-402.

Ashton, P.J., Appleton, C.C. \& Jackson, P.B.N. 1986. Ecological impacts and economic consequences of alien invasive organisms in southern African ecosystems. In: Macdonald, I.A.W., Kruger, F.J. \& Ferrar, A.A. (eds). The ecology and management of biological invasions in southern Africa. Cape Town: Oxford University Press, pp. 247-257.

Berrie, A.D. 1968. Prolonged inhibition of growth in a natural population of the freshwater snail Biomphalaria sudanica tanganyicensis (Smith) in Uganda. Annals of Tropical Medicine and Parasitology, 62: 45-51.

Brackenbury, T.D. \& C.C. Appleton. 1991. Effect of controlled temperatures on gametogenesis in the gastropods Physa acuta (Physidae) and Bulinus tropicus (Planorbidae). Journal of Molluscan Studies, 57: 461-469.

Brackenbury, T.D. \& Appleton, C.C. 1993. Recolonization of the Umsindusi River, Natal, South Africa, by the invasive gastropod, Physa acuta (Basommatophora, Physidae). Journal of Medical \& Applied Malacology, 5: 39-44.

Brown, D.S. 1967. A review of the freshwater Mollusca of Natal and their distribution. Annals of the Natal Museum, 18: 477-494. 
Brown, D.S. 1978. Freshwater molluscs. In: Werger, M.J.A. (ed.) Biogeography and ecology of southern Africa 2. The Hague: Junk, pp. 1155-1180.

Brown, D.S. 1980. Freshwater snails of Africa and their medical importance. London: Taylor \& Francis Ltd.

Brown, D.S. 1994. Freshwater snails of Africa and their medical importance, $2^{\text {nd }}$ edition. London: Taylor \& Francis.

Chernin, E. \& Michelson, E.H. 1957. Studies on the biological control of schistosome-bearing snails. IV: Further observations on the effects of crowding on the growth and fecundity in Australorbis glabratus. American Journal of Hygiene, 65: 71-80.

Connolly, M. 1939. A monographic survey of South African non-marine Mollusca. Annals of the South African Museum, 33: $1-660$.

De Kock, K.N., Joubert, P.H. \& Pretorius, S.J. 1989. Geographical distribution and habitat preferences of theinvader freshwater snail species Lymnaea columella (Mollusca: Gastropoda) in South Africa. Onderstepoort Journal of Veterinary Research, 56: 271-275.

De Kock, K.N. \& Wolmarans, C.T. 1998. A re-evaluation of the occurrence of freshwater molluscs in the Kruger National Park. Koedoe, 41: 1-8.

De Kock, K.N., Wolmarans, C.T., Bornman, M. \& Maree, D.C. 2002. Verspreiding en habitats van Bulinus tropicus, tussengasheerslak van die peervormige bot, Callicophoron microbothrium, in Suid-Afrika. Suid-Afrikaanse Tydskrif vir Natuurwetenskap en Tegnologie, 21: 114-120.
De Kock, K.N., Wolmarans, C.T. \& Du Preez, L.H. 2002. Freshwater mollusc diversity in the Kruger National Park: a comparison between a period of prolonged drought and a period of exceptionally high rainfall. Koedoe, 45: 1-11.

DeWitt, R.M. 1954. Reproductive capacity in a pulmonate snail (Physa gyrina Say). American Naturalist, 88: 159-164.

Hamilton-Attwell, V.L., De Kock, K.N. \& Van Eeden, J.A. 1970. The occurrence and distribution of Physa acuta Draparnaud in the Republic of South Africa. Wetenskaplike Bydraes van die Potchefstroomse Universiteit vir Christelike Hoër Onderwys, Reeks B: Natuurwetenskappe, 26: 1-11.

Oberholzer, G. \& Van Eeden, J.A. 1967. The freshwater molluscs of the Kruger National Park. Koedoe, 10: 1-42.

Pointier J.P. 1999. Invading freshwater gastropods; some conflicting aspects for public health. Malacologia, 41: 403-411.

Rees, W.J. 1965. The aerial dispersal of Mollusca. Proceedings of the Malacological Society of London, 36: 269-273.

Van Bruggen, A.C. 1964. The distribution of introduced mollusc species in southern Africa. Beaufortia, 11: 161-169.

Van Eeden, J.A. \& Brown, D.S.. 1966. Colonization of fresh waters in the Republic of South Africa by Lymnaea columella Say (Mollusca: Gastropoda). Nature, 210: 1172-1173.

Wolmarans, C.T. \& De Kock, K.N. 2006. The current status of freshwater molluscs in the Kruger National Park. Koedoe, 49: 39-44. 